\title{
Isolation and Identification Causal Agent of Callistemon sp. Seedlings Root Rot
}

\author{
Goner A. Shaker \\ Iraq Natural History Museum, University of Baghdad, Baghdad-Iraq.
}

\begin{abstract}
Isolation and identification of the fungi which causes the root rot disease of Callistemon sp. trees in AL-Alaab city, Al- Zawra garden and Al- Jaderiia in Baghdad provinces reveled diagnosis of the following fungi: Fusarium solani, F. oxysporum, F. moniliiforme, Rhizoctonia solani, Curvularia lunata, Cladosporiun herbarum, Aspergillus niger, A. flavus, Theilaviopsis, Mycelia sterilia, The frequency percentages of the isolated fungi from root and foliar system, in the three locations ranging from 10-60\% and the highest percentages were $60 \%$ for F.solani in AL-Alaab city, $40 \%$ in AL-Jadeeria as compared to other fungi. The percentage of the disease severities were 25, 10.4, 2.1, $0 \%$ for $R$. solani, F. solani, $C$. lunata and Control, respectively. The seed germination percentages which treated with $F$. solani, $R$. solani, $C$. lunata were 20, 20, $90 \%$, respectively, and seedling damping-off percentages were 60,20 and $10 \%$ for the same fungi respectively and showed significant differences $(\mathrm{p} \leq 0.05)$ among treatments. This is the first record of the disease on Callistemon sp. trees in Iraq.
\end{abstract}

Keywords: Callistemon sp., root rot, F. moniliiforme, Rhizoctonia solani, Curvularia lunata.

\section{Introduction}

The bottle brush is the common name of Callistemon sp, it is a popular ornamental tree in subtropical areas, typically growing as a perennial and described as evergreen plant, bright red flower spikes, planting in container or above-ground like espalier, hedge, and parking. The genus includes 30 species of trees and shrubs belong to Myrtaceae family, they are all native to Australia [1, 2, 3, and 4]. The tree can be reproduced vegetatively using cuttings and by seeds [2]. These trees have many benefits and used of such maximum amount of nectar sugars in the flowers of bottle brush, $C$. lanceolatus, prouduced $6.044 \mathrm{mg} /$ flower sugar $72 \mathrm{hrs}$ after flower opening, whereas the $24 \mathrm{hrs}$ sugar value was only $0.44 \mathrm{mg}$. Apis mellifera harvested $\approx 90 \%$ of the sugar produced by the flowers [5]. The aqueous extracts of Eucalyptus lanceolatus and $C$. citrinus plants showed strong antifungal activity against Chaetomium sp., Alternaria alternata and Aspergillus niger fungi [6]. The aqueous and alcoholic extracts of different parts of bottle brushes Callistemon were found to have various pharmacological activities. For example, antifungal, antioxidant, antithrombin, anti-inflammatory, antidiabetic, antimicrobial and herbicidal activities [7]. These trees are susceptible to harmful diseases and fungal infections that can kill it, or at least severely affect its growing during a recent survey in Tunisia[8], a number of Calonectria spp. were showed symptoms of leaf spot, crown and root rot on seedlings of Callistemon spp. The damping-off and leaf spot caused by Cylindrocladium scoparium on bottle brush cuttings in Italy in May of 2006, has been observed [9]. Also, Phytophthora root rot is a disease that infects Callistemon sp. plants, the fungus infects the root systems and causing yellowing of leaves, early defoliation, reddish-brown roots, the dieback of branches and the discolouration of branches [2]. This study was designed to determine the causal fungal root rot to Callistemon sp. seedlings.

\section{Materials and Methods \\ 1-Sampling, isolation and diagnosis}

Survey was conducted on three sites included AL-Alaab city, Al- Zawra garden and Al- Jaderiia in Baghdad province. The bottle brush Callistemon sp. trees showed symptoms of dieback, discolouration of branches, decline and death in nurseries. A survey was conducted and the roots were collected from a depth of $30-50 \mathrm{~cm}$. Samples were kept in polyethylene bags, brought to the laboratory, placed under running water for an hour and cut to a small pieces $(0.5 \mathrm{~cm})$ and sterilized with $1.5 \%$ solution of sodium hypochlorite for 2-3 minutes and washed with sterile distilled water then dried by filter papers, 3-4 pieces per Petri- dish were transferred into PDA and 
placed inside an incubator at $25^{\circ} \mathrm{C} \pm 1$ until fungal growth emergence. Slides were prepared from isolated fungi and diagnosed to the level of species according to taxonomic keys $[10,11]$. The percentage of appearance frequency for each fungus was also calculated by using the following equation:

\section{The percentage of frequency \\ $=\frac{\text { No.pieces colonized by the fungus } \times 100}{\text { Total no.cultured pieces }}$}

\section{2-Pathogenicity test}

To reveal pathogenicity, most frequent fungi were used Rhizoctonia solani, Fusarium solani, Curvularia lunata and as follows:-

Inoculum preparation: suspension solution of conidiospores Fusarium solani and Curvularia lunata was prepared at concentration of spores $1 \times 10^{5}$ Spore $/ \mathrm{ml}$ of pure culture 7 days old on Potato Dextrose Agar which was estimated by Haemocytometer.

Seedlings preparing: bottle brush seedlings $50 \mathrm{~cm}$ long with similar external appearance in regard to size and shape, healthy were prepared, Seedlings were planted in containers (sand: peat moss) (1: 2) and sterilized by isteam (autoclave at $121{ }^{\circ} \mathrm{C}$ and under 15 pound/ square inch) forth and irrigated with sterile water. Seedlings were infected with the suspension solution of the spores of $F$. solani, $C$. lunata and pure culture of $R$. solani, by injecting $2 \mathrm{ml}$ of the suspension solution of spores $F$. solani, $C$. lunata on the roots crown. In crown adjacent to soil surface a wound was done by sterile knife and inoculated with small piece of $R$. solani inoculum, wrapped with cellophane paper after covering by cotton then moistened with sterile distilled water to maintain moisture. All treatments were replicated three times, the control treatment of seedlings was injected with $2 \mathrm{ml}$ sterile distilled water using a piece of PDA in the control treatment of $R$. solani.

The disease severity was calculated by disease index according to the scale mentioned by [12], which consists of five degrees: 0 . There is no infection, 1. 1-25\% of the seedling are yellowish, 2. 26-50\% of the seedling wilting and yellowing in branches, 3. 51-75\%
Yellowing and wilting, 4. 100\% Wilting Seedling, according to the following equation mentioned by [13].

Disease index $(\mathrm{DI})=$

No.leaves in degree $0 \times 0$...No.leaves in degree $4 \times 4$

No of leave alldegrees XMax.degree of infection $\times 100$

3-Seeds germination percentage treated with isolated fungi

Percentage of germinating seeds were contaminated with the fungi $R$. solani, $F$. solani, $C$. lunta, seed were planted (20 seeds/ dish) after one week from the date of soil contaminating with fungi in ceramic dishes container $25 \mathrm{~cm}$ diameter, the soil is composed of (sand: peat moos) (1:2) sterilized by autoclave at $121^{\circ} \mathrm{C}$ under pressure 15 pounds/ square inch, for $1 \mathrm{~h}$ and treatments were prepared as follows:

1- The seeds planted in soil contaminated with the suspension solution of spores of F.solani concentration of $1 \times 10^{5}$ Spore / ml. 2- The seeds planted in soil contaminated with the suspension solution of spores of $C$. lunata a concentration of $1 \times 10^{5}$ Spore / ml. 3- The seeds planted in soil contaminated with the fungus $R$. solani by $1 / 2$ dish of pure culture. Treatments left in the field until the seeds germinated. Each treatment replicated three time and used only sterile water in control treatment, the percentage of seed germination and seedling damping off were account after 10-30 days from seed germination according to the following equations:-

\section{$\begin{aligned} & \text { The percent of } \\ & \text { eeds germination }\end{aligned}=\frac{\text { The no. of grown seed }}{\text { Total no. of seeds }} \times 100$}

$$
\begin{gathered}
\text { The percent of } \\
\text { damping off }
\end{gathered}=\frac{\text { No.of dead seedlings }}{\text { No.of total seedlings }} \times \mathbf{1 0 0}
$$

\section{Results and Discussion \\ 1-isolation and diagnosis}

The isolation of the fungi causes of the root rot bottle brush seedlings in Baghdad province in the sites, Al-Alaab city, Al- Zawra garden and Al-Jaderiia yielded: Fusarium solani, Fusariam oxysporum, Fusarium moniliiforme, Rhizoctonia solani, Curvularia lunata, Cladosporium herbarum, Aspergillus niger, Aspergillus flavus, Theilaviopsis sp, Mycelia sterilia. The ferquency percentage of fungi in the three locations was ranging from $10-60 \%$. Where the highest percentage of fungi F.solani 
was $60 \%$ in AL-Alaab city and $30 \%$ in Al- Jaderiia. The ferquency percentage of fungi R.solani 25, 25, $20 \%$ in Al- Jaderiia, Al-Zawra garden, AL-Alaab city, respectively, The appearance percentage of fungi $F$. moniliiforme, $F$. oxysporum was 20 and $10 \%$ in the AL-Alaab city, which showed that the fungi were appeared in larger proportions in isolates of AL-Alaab city, as in Table (1). There is a clear difference in the number of species of fungi isolated from the root regions for isolated from branches area, as shown in Table (2) and that is where $F$. solani appeared in the isolates roots and branches, while $R$. solani appeared in isolates roots only, as was $C$. lunata appearance in isolates branches area larger compared to isolates root regions at all locations, this could explain the role of fungi pathogens may be more power and highest impact in the case of infection by the roots and branches together compared to the case of infection by the roots or branches each separately. We infer that these fungi may infect in nurseries and then transported to the forests, field and gardens through the infected seedlings and are leading to appear symptoms on seedlings and death of these trees.

Table (1)

The percentage of frequency of fungi isolated from bottle brush Callistemon sp. trees infected with root rot in three locations.

\begin{tabular}{|c|c|c|c|}
\hline \multirow[b]{2}{*}{ Fungi } & \multicolumn{3}{|c|}{$\begin{array}{c}\text { Fungal appearance } \\
\text { frequency } \%\end{array}$} \\
\hline & $\underset{\text { Jaderiia }}{A l-}$ & $\begin{array}{c}\text { Al- } \\
\text { Zawa } \\
\text { gardn } \\
\end{array}$ & $\begin{array}{c}A L- \\
\text { Alaab } \\
\text { city }\end{array}$ \\
\hline Fusarium soloni & 30 & 10 & 60 \\
\hline Fusarium oxysporum & 30 & 0 & 10 \\
\hline Fusarium moniliiforme & 0 & 0 & 20 \\
\hline Rhizoctonia solani & 25 & 25 & 20 \\
\hline Curvularia lunata & 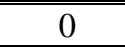 & 10 & 40 \\
\hline Cladosporiumherbarum & 0 & 10 & 10 \\
\hline Theilaviopsis & 0 & 0 & 5 \\
\hline Aspergillus niger & 10 & 10 & 35 \\
\hline Aspergillus flavus & 20 & 20 & 0 \\
\hline Mycelia sterilia & 20 & 20 & 20 \\
\hline
\end{tabular}

Table (2)

The presence of fungal isolates from the roots and branches of infected bottle brush Callistemon sp. trees infected with root rot.

\begin{tabular}{|c|c|c|c|c|c|c|}
\hline \multirow[t]{2}{*}{ Fungi } & \multicolumn{2}{|c|}{$\begin{array}{c}\text { Al- } \\
\text { Jaderiia }\end{array}$} & \multicolumn{2}{|c|}{$\begin{array}{c}\text { Al- } \\
\text { Zawra } \\
\text { garden } \\
\end{array}$} & \multicolumn{2}{|c|}{$\begin{array}{c}A L- \\
\text { Alaab } \\
\text { city } \\
\end{array}$} \\
\hline & $\boldsymbol{B}$ & $\boldsymbol{R}$ & $\boldsymbol{B}$ & $\boldsymbol{R}$ & $\boldsymbol{B}$ & $R$ \\
\hline Fusarium soloni & + & + & + & + & + & + \\
\hline Rhizoctonia solani & - & + & - & + & - & + \\
\hline Fusarium oxysporum & + & - & - & - & + & + \\
\hline Fusarium Moniliforme & - & - & - & - & + & + \\
\hline Curvularia lunata & - & - & + & - & + & + \\
\hline $\begin{array}{l}\text { Cladosporium } \\
\text { herbarum }\end{array}$ & - & - & + & + & + & + \\
\hline Theilaviopsis & - & - & - & - & + & - \\
\hline Aspergillus niger & + & - & - & + & + & - \\
\hline Aspergillus flavus & + & - & 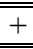 & - & - & - \\
\hline Mycelia sterilia & + & + & + & + & + & + \\
\hline
\end{tabular}

(+) presence of fungus, (-) No fungus. $R=$ Roots, $B=$ Branches

\section{2-Pathogenicity test}

Clearly, the results in Table (3) To test the pathogenicity on the ability of each of the fungi $R$. solani, $F$. solani, $C$. lunata on the occurrence of the disease, and the incidence percentages were 25, 10.4 and $2.1 \%$, respectively, while the control treatment showed $0 \%$, The appearance of the disease on the root systems and cause yellowing of leaves, early defoliation, reddish-brown roots, and change the color of the branches Fig.(1).and there were significant differences between treatments at $\mathrm{P} \leq 0.05$ differences. It was re-isolate the fungus from the roots of seedlings inoculated. It is noticeable that there is variation in the ability of fungal pathogenicity may be due to various effects of the surrounding environmental conditions.

Table (3)

The incidence percentage of infection with fungi C. lunata, R. solani, F. solani for seedlings bottle brush Callistemon sp. trees.

\begin{tabular}{|c||c|}
\hline Fungi & Disease index \% \\
\hline \hline R.solani & $25.0 *$ \\
F.solani & 10.4 \\
C.lunata & 02.1 \\
Control & 00.0 \\
\hline
\end{tabular}

${ }^{*}$ LSD at 0.05 probability level $=16.9$ 


\section{3-Seeds germination treated with isolated fungi}

The results showed that the percentage of seeds germination treated with fungi $C$. lunata, $R$. solani, $F$. solani was $90,20,20 \%$ respectively, and $0 \%$ for the control treatment, Table (4). Because $F$. solani and $R$. solani of soil fungi and they are the reason for the phenomenon of lack of seed germination and seedling death, $C$. lunata has little effect in reducing the rate of seed germination The percentage of seedling damping off for fungi $C$. lunata, $R$. solani, F. solani was 10,20 , and $60 \%$. The researchers $[14,15]$ indicated to the fact that the infected seeds and vectors of pathogenic fungi may causes a reduction in the percentage of seed germination especially if they are not properly stored, and not collected in a timely manner and proper drying and good storage is necessary to protect the seeds from rotting and damage, If the soil is too moist, the root and crown will attacking by fungi diseases and can be a problem [1].

\section{Table (4)}

Percentages of seeds rot and seedlings damping off bottle brush Callistemon sp trees.

\begin{tabular}{|c||c||c||}
\hline Treatments & $\begin{array}{c}\text { Seedlings } \\
\text { damping off after } \\
\text { emergence \% }\end{array}$ & $\begin{array}{c}\text { Seeds rot } \\
\text { before } \\
\text { emergence\% }\end{array}$ \\
\hline \hline F.solani & 60 & $* 20$ \\
R.solani & 20 & 20 \\
C.lunata & 10 & 90 \\
\hline
\end{tabular}

$*$ LSD at 0.05 probability level $=0.14$

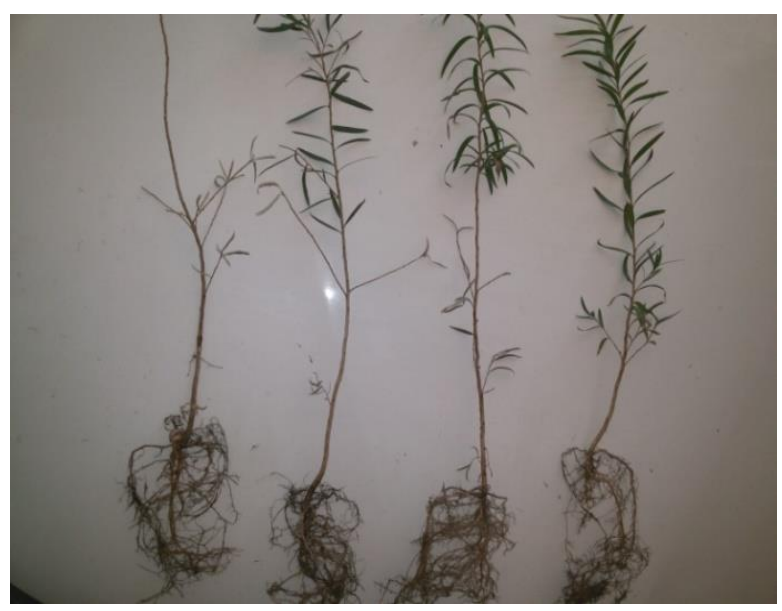

Fig.(1) Pathogenicity test show the symptoms on the bottle brushes Callistemon sp. treated with, 1- R. solani, 2- F. solani, 3- C. lunata, 4- control .(from left to right).

\section{References}

[1] Edward F. G. and Dennis G. W. Dwarf Bottlebrush Callistemon citrinus 'Little John'. Horticulture. University of Florida Equal Opportunity Institution, 2008.

[2] Bottlebrush (Callistemon) species. Department of Agriculture, Forestry and Fisheries. www.flowerite.co.za and www.theflowerexpert.com. 2012.

[3] Elliot, W. R. and Jones, D. L. Encyclopedia of Australian Plants, 2, Lothian Publishing Company, Australia, 1982.

[4] Chenielle, D. Lois, R. Alison, N. Sylvia, M. John, L.and Mohammed A. Antibacterial and antifungal analysis of crude extracts from the leaves of Callistemon viminalis. Journal of Medical and Biological sciences. 3(1), 2009.

[5] Gupta, J. K. and Kumar, J. Bottle brush Callistemon lanceolatus DC (Myrtaceae) nectar: amount, type of nectar sugars and honeybee foraging. Apidologie. 24 (6), 564568, 1993.

[6] Swapna K. and Lalchand D. Antifungal Activity of Aqueous Plant Extracts against Some Book Deteriorated Fungi. International Journal of Engineering Science and Innovative Technology (IJESIT). 2(6), 2013.

[7] Sanjita, D. and Uttam, S. Therapeutic potentials of Callistemon lanceolatus DC, International Journal of Advances in Pharmacy, Biology and Chemistry (IJAPBC). 1(2), 206-210, 2012.

[8] Lombard, L. Polizzi, G. Guarnaccia, V. Vitale, A. and Crous, P. W. Calonectria spp. causing leaf spot, crown and root rot of ornamental plants in Tunisia. Persoonia: Molecular Phylogeny and Evolution of Fungi. 27: 73-79, 2011.

[9] Polizzi, G. Vitale, A. Aiello, D. and Dimartino, M. A. First Report of DampingOff and Leaf Spot Caused by Cylindrocladium scoparium on Different Accessions of Bottlebrush Cuttings in Italy. The American Phytopathological Society. 91(6) 769, 2007.

[10] Barnett, H. L. Illustrated genera of imperfect fungi, second edition. Buijess Publishing com. U.S.A. 1965. 
[11] Domsch, K. H., Gams, W. and Anderson, T.H. Compendium of soil fungi. Academic Press. A subsidiary of Harcourt Brace Jovanoich, Publishers .2, 1980.

[12] Abu Bakar, A. I. Nur Ain Izzati, M. S. and Umi kalsom, Y. Diversity of Fusarium species associated with post- harvest Fruit Rot Disease of Tomato. Sains Malaysiana, 42(7), 911-920, 2013.

[13] Parimala, R. D. and Marimuthu, P. Effect of Botanical Formulation of Polygonum minus (P-40) on control of Alternaria solani. Plant pathology and microbiology. 2(1), 104, 2011.

[14] Chacko, K.C. and Mohanan, C. Development of technology for collection, processing and testing seeds of important tree species of Kerala Final Technical Report (ICFRE). Kerala Forest Research Institute, Peechi, Kerala, India, 2002.

[15] Mohanan, C. chacko, K.C. chandran, A. and Varma, G. Seed health problems in tropic Forest tree seeds and their impact on seedling production. Working papers of the Finnish Forest Research Institute11. http://www.melta.Fi/ Julkaisut/ working. Papers /2005 /mwpoll. htm. 83-93, 2005.
الخلاصة

أظهرت دراسـة عزل وتشـخيص المسببات الفطريسة لتعفن

Callistemon sp. الجذور شتلات أشجار فرثـة البطل لمواقـع مدينـة الألعـاب ومتتـزه الـزوراء ومجمـع الجادريـة في مدينة بغداد عن نشخيص الفطريات:

Fusarium solani, Fusarium oxysporum, Fusarium moniliiforme, Rhizoctonia soloni, Curvularia lunata, Cladosporium herbarum, Aspergillus niger, Aspergillus flavus, Theilaviopsis sp, Mycelia sterilia.

التي عزلت من المجموع الجذري والخضري وكانت نسبة

تكرار ظهور الفطريـات في المواقـع الثلاثتة تــراوح مـا بيـن 10-60 \% وكانـت اعلى نسبة للفطر F.solani وهي 60 في مدينة الألعاب و 40\% في مجمع الجادرية مقارنة بالفطريات الأخرى. بينما كانت النسبة المئوية لشدة ألاصـابة C.lunata, F.solani , 25 ، على التوالي وكانت في معاملـة المقارنـة صفر

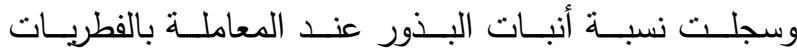
\% 90,20,20 C. lunata, F. solani, R.solani على التوالي. ونسـب مـوت البـادرات 10,20,60 \% على التوالي وظهرت وجـود فروقات معنوبـة مـا بين عند مستوى احتــال 0.05 مـابين المعـاملات. وهـذا يعد التسـيل الأول للمرض على شتلات أشجار فرشة البطل في العراق. 